\title{
The Processing Effects of Anthocyanins Extracted from Dragon Fruit (Hylocereus polyrhizus) Peel on Total Amount of Anthocyanins and SEM Image in Poultry Nutrition
}

\author{
Yusuf Mahlil ${ }^{1}$, Husmaini $^{2}$, Warnita $^{3}$, Mirzah $^{4}$, Mime Kobayashi $^{5}$ and Maria Endo Mahata ${ }^{4 *}$ \\ ${ }^{1}$ Department of Agriculture Science, Faculty of Agriculture, Andalas University, 25163, Indonesia \\ ${ }^{2}$ Department of Animal Production, Faculty of Animal Science, Andalas University, 25163, Indonesia \\ ${ }^{3}$ Departmen of Agronomy, Faculty of Agriculture, Andalas University, 25163, Indonesia \\ ${ }^{4}$ Department of Animal Nutrition and Feed Technology, Faculty of Animal Science, Andalas University, 25163, Indonesia \\ ${ }^{5}$ Division of Biological Science, Nara Institute of Science and Technology, 8916-5 Takayama-cho, Ikoma, Nara 630-0192, Japan \\ *Corresponding author's Email: maria@ ansci.unand.ac.id; ORCID: 0000-0000-0000-0000
}

Received: 07 Jul. 2020

Accepted: 21 Aug. 2020

\begin{abstract}
The purpose of present study was to know the effects of different processing of anthocyanin content and scan electron microscope image of anthocyanin of dragon fruit peel in poultry diet. The experiment was performed in a completely randomized design with different processing like untreated dragon fruit peel or control, physical, chemical, biological, and physical-biological, and each treatment was replicated 4 times. Variables measured were total amount of anthocyanin and anthocyanin image of dragon fruit peel. The results indicated that physical treatment significantly increased anthocyanin content of dragon fruit peel. Furthermore, treated dragon fruit peel with chemical, biological, and combination of physical-biological significantly reduced anthocyanin content. The image of anthocyanin from each treated processing revealed that control image was similar to physical treatment, and it was different from other treatments. The physical treatment was the best method to increase anthocyanin content, and did not change the image of anthocyanin from dragon fruit peel.
\end{abstract}

Keywords: Anthocyanins, Dragon fruit peel, Processing, Scanning electron microscope, Spectrophotometry

\section{INTRODUCTION}

Dragon fruit is a fruit from cactus plant which have many different species such as white dragon fruit (Hylocereus undatus), red dragon fruit (Hylocereus polyrhizus), super red dragon fruit (Hylocereus contaricensis), and yellow dragon fruit (Selenicereus megalanthus). The most popular dragon fruit in Indonesia is red dragon fruit (Hylocereus polyrhizus), this dragon fruit is used by people to make a juice, cake, syrup, and jam, where all these processings will produce dragon fruit peel waste. There is no report about total production of dragon fruit in Indonesia, but Mahata et al. (2015) and Mahlil et al. (2018a) reported that processing and utilization of the fresh dragon fruit (Hylocereus polyrhizus) would produce dragon fruit peel waste as much as $22 \%$ from the whole fruit. In Indonesia, the dragon fruit peel waste is potentially as poultry feed for lowering cholesterol, and as antioxidant (Mahata et al., 2015; Mahlil et al., 2018a). The phytochemical in dragon fruit peel such as anthocyanins, beta-carotene, and lycopene were reported as antioxidants, lowering the blood cholesterol, natural dyes, and anti-cancer (Wu et al., 2006; Charoensiri et al., 2009). According to Lewis and Rader (2005) and Anggraeni (2010), the mode of action of anthocyanin in reducing of LDL cholesterol in mice and humans was by inhibiting of 3-hydroxy-3-methyl-glutarylcoenzyme A (HMG-CoA) reductase enzyme for producing mevalonate from HMG-CoA compound in cell. In addition, anthocyanin was reported to increase the activity of lecithin cholesterol acyltransferase to convert free cholesterol to hydrophobic cholesterol ester, then the cholesterol ester binds the lipoprotein core to produce new HDL, this reaction increased the blood plasma HDL in humans and mice. Fang (2014), reported that Anthocyanin compounds can be absorbed from the stomach or intestines. Anthocyanin can bind to proteins, so they can accumulate into egg yolks, and increase egg yolk color (Fayyaz et al., 2016; Iskander et al., 2017).

To cite this paper: Mahlil Y, Husmaini, Warnita, Mirzah, Kobayashi M and Endo Mahata M (2020). The Processing Effects of Anthocyanins Extracted from Dragon Fruit (Hylocereus polyrhizus) Peel on Total Amount of Anthocyanins and SEM Image in Poultry Nutrition. J. World Poult. Res., 10 (3): 513-519. DOI: https://dx.doi.org/10.36380/jwpr.2020.59 
Previous researches showed that processing of poultry feed by physical methods (steaming, boiling), chemical methods like submerge in acid or base solution, biological method like fermentation with microorganism were performed for improving the quality of poultry feed (Mahlil et al., 2018a). Mahata et al. (2016a) and Mahata et al. (2016b) reported that the processing of tomato waste by physical method (boiled in hot water for eight minutes) to change the structure of trans-lycopene to cis-lycopene in tomato waste showed that tomato waste can be used as an alternative feed for broiler and laying hens. The utilization of boiled tomato wastes can be used as much as $7 \%$ in broiler ration, and as much as $12 \%$ in laying hens ration (Mahata et al., 2016a; Mahata et al., 2016b). Furthermore, Handayani et al. (2018) mentioned that physical method (steaming and boiling) of tomato waste for 12 minutes was the appropriate process for increasing lycopene and organic matter content, and maintaining the crude protein content. Mahata et al. (2012) reported that the crude fiber content in a juice waste mixture decreased from 17.10 to 12.02 percent after steaming in an autoclave for 30 minutes. Mahlil et al. (2018a) reported that the processing of dragon fruit peels by physical method (steaming for 20 minutes), and chemical method (soaking in acetic acid solution for four hours) decreased the crude fiber content in dragon fruit peel from 24.01 to 19.81 percent, and from 24.01 to 20.39 percent, respectively. Crude fiber content in poultry's feed was decreased by biological method such as fermentation using microorganism (Rizal et al., 2013; Adrizal et al., 2017; Heryandi et al., 2018; Mahlil et al., 2018b)

The problem of dragon fruit peel utilization for laying hen diet was the high value of crude fiber content (24\%) (Mahlil et al., 2018). The digestive tract of poultry does not produce cellulase enzyme for degrading fiber, therefore the anthocyanin in dragon fruit peel was not absorbed by poultry maximally (Mahlil et al., 2018). Furthermore, dragon fruit peel waste must be processed by some methods to decrease crude fiber content before it is utilized for laying hens feed.

The processing of dragon fruit peel by some methods like heating and soaking with alkali and acid solution would destroy its anthocyanin structure and quantity, because some factors like $\mathrm{pH}$, temperature, light, metal ion, oxygen, sugar content, and enzyme will affect the anthocyanin stability and quantity (Khazaei et al., 2014; Khoo et al., 2017). In present experiment, the anthocyanin content from dragon fruit peel after treated by all methods (physical, chemical, biological, and combination of physical-biological method) was detected by spectrophotometer. It was also seen the figure of anthocyanin after treated by any possible method (physical, chemical, biological, and combination of physical-biological method) under scan electron microscope (SEM).

\section{MATERIALS AND METHODS}

\section{Collection of dragon fruit peel}

Dragon fruit peels (Hylocereus polyrhizus) were obtained from dragon fruit field in Payakumbuh City, and also from restaurants and various juice counters in Padang City, West Sumatra Province, Indonesia.

\section{Experimental design}

The experiment was performed in a completely randomized design with different processing like untreated dragon fruit peel or control, physical (steaming at $98^{\circ} \mathrm{C}$ for 20 minutes), chemical (soaking in 7.5\% acetic acid, $\mathrm{pH}$ of 4 for duration of four hours), biological (fermentation using local microorganism solution from bamboo sprout with fermentation durations of 13 days, and inoculum dosage 6\%), and physical-biological, and each treatment was replicated 4 times. Variables measured in the experiment were anthocyanin contents and anthocyanin image of dragon fruit peel.

\section{Preparation of dragon fruit sample}

The sample of dragon fruit peel used in this experiment was obtained from restaurant and juice counters. Furthermore, dragon fruit peel was treated by some methods such as physical (steaming for 20 minutes), chemical method (soaking in acetic acid solution for four hours) (Mahlil et al., 2018a), biological method with fermentation utilizing microorganism-containing solution from local bamboo sprout like Lactobacillus, Streptococcus, Azotobacter, Azospirilium and fungi (Fusarium and Trichoderma) with fermentation duration of 13 days, and inoculum dosage of $6 \%$, and combination of the physical and the biological processing methods (Mahlil et al., 2018b). After processing by each method, the dragon fruit peel was dried in oven with temperature of $60^{\circ} \mathrm{C}$ until getting dry, and then it was blended to mash form.

\section{Anthocyanin extraction}

Anthocyanin extraction was prepared by maceration method by using distilled water solvent (Lapornik et al., 
2005). Two gram of dragon fruit peel mash sample from each different method processing (steaming 20 minutes, soaking in acetic acid solution for four hours, fermentation utilizing microorganism-containing solution from bamboo sprout, combination of the physical and the biological) were macerated in Erlenmeyer flask volume $250 \mathrm{ml}$, and the surface of Erlenmeyer was covered with aluminum foil, and then they were placed at a hot plate for extraction process (Lapornik et al., 2005). Furthermore, samples were centrifuged at a cold centrifuge $\left(4^{\circ} \mathrm{C}\right)$ with $8000 \mathrm{rpm}$, and the supernatant (anthocyanin) of each sample were separated from pellet, and then dried at oven in temperature of $60^{\circ} \mathrm{C}$.

\section{Calculation of total anthocyanin}

Total anthocyanin was calculated by Giusti et al. (2001) method used spectrophotometer (UV-Visible 1700, Shimadzu). As much as one $\mathrm{ml}$ of anthocyanin extract from each different processing method of dragon fruit peel was diluted into two different buffer solutions. For the first solution, the dragon fruit peel sample was diluted with $0.025 \mathrm{M}$ of Potassium Chloride buffer at $\mathrm{pH}$ of 1 , and the second solution was diluted with $0.4 \mathrm{M}$ buffer of natrium acetate at $\mathrm{pH}$ of 4.5 (Giusti et al., 2001). For determination of anthocyanin content and lambda visible maximum of sample solution in both buffer (Potassium chloride and natrium acetate), the scanning of wave length in $510 \mathrm{~nm}$ to $700 \mathrm{~nm}$ was arranged in spectrophotometer, and then absorbance was measured (Giusti et al., 2001). Furthermore, total anthocyanin was calculated with mathematical equation below:

Absorbance of solution: [lambda visible maximum $(510 \mathrm{~nm})-\mathrm{A} 700 \mathrm{~nm}] \mathrm{pH} 1.0$ - [lambda visible maximum $(510 \mathrm{~nm})-700 \mathrm{~nm}] \mathrm{pH} 4.5$

Monomeric total of anthocyanin from dry extract of dragon fruit peel after each processing method was calculated as cyaniding-3- glucoside base on mathematical equation below:

$\operatorname{MAP}(\mathrm{mg} / \mathrm{L}):[(\mathrm{A} \times \mathrm{MW} \times \mathrm{DF} \times 1000) /(\varepsilon) \times 1]$

A: absorbance of solution; MW: molecular weight; DF: dilution factor; $\varepsilon$ : absorptivity molar cyaniding-3glucoside; 1: thick cuvette $(\mathrm{cm})$; MAP: monomeric anthocyanin pigment

\section{Scanning electron microscope observation of anthocyanin}

The anthocyanin sample was attached to the carbon tape, and then put on the metal plate (Echlin, 2009).
Furthermore, samples were sputter-coated with gold (50 nm) using a VPS-020 quick coater (ULVAC Inc., Kanagawa, Japan) for observation by SEM (SU-6600, Hitachi High-Technology Corp., Tokyo, Japan) at an acceleration voltage of $1.0 \mathrm{kV}$ (Echlin, 2009).

\section{Statistical analysis}

All data were statistically analyzed by a one-way analysis of variance (completely randomized design). The differences between treatments were determined using Duncan's multiple range test, with a 5\% significance level $(\mathrm{P}<0.05)$ (Steel and Torrie, 1991).

\section{RESULTS AND DISCUSSION}

The mean values of the anthocyanin content in dragon fruit peel before and after treated with each method are depicted in table 1 . The processing of dragon fruit peel with some methods (control, physical, chemical, biological, and combination of physical biological) affected anthocyanin content significantly $(\mathrm{P}<0.05)$. Anthocyanin content from physical treatment was significantly different $(\mathrm{P}<0.05)$, higher than control, chemical, biological, and combination of physical biological treatments. Control treatment was significantly different $(\mathrm{P}<0.05)$, higher than chemical, biological, and combination physical-biological. Chemical treatment was significantly different $(\mathrm{P}<0.05)$, higher than biological and combination of physical-biological, and anthocyanin content of biological treatment was significantly different $(\mathrm{P}<0.05)$, higher than anthocyanin content from combination of physical-biological treatments.

Table 1. The Amount of total anthocyanin (ppm) content in dragon fruit peel (Hylocereus polyrhizus) before and after treated by Physical, Chemical, Biological and Physical-Biological methods

\begin{tabular}{|c|c|c|c|c|c|}
\hline \multirow{2}{*}{ Treatment } & \multicolumn{4}{|c|}{ Replication } & \multirow{2}{*}{ Means } \\
\hline & $\mathbf{A}$ & B & $\mathrm{C}$ & D & \\
\hline Control & 201.54 & 212.22 & 187.53 & 194.20 & $198.87^{\mathrm{a}}$ \\
\hline Physical & 351.70 & 345.03 & 373.72 & 149.49 & $353.20^{\mathrm{b}}$ \\
\hline Chemical & 134.14 & 147.49 & 148.82 & 142.35 & $144.98^{\mathrm{c}}$ \\
\hline Biological & 111.45 & 112.12 & 113.45 & 114.79 & $112.95^{\mathrm{d}}$ \\
\hline $\begin{array}{l}\text { Physical- } \\
\text { Biological }\end{array}$ & 46.05 & 48.72 & 45.38 & 44.71 & $46.21^{\mathrm{e}}$ \\
\hline
\end{tabular}


The processing of dragon fruit peel by physical method (steaming at $98^{\circ} \mathrm{C}$ for 20 minutes) increased anthocyanin content of dragon fruit peel from 198.87 to $353.20 \mathrm{ppm}$. Furthermore, processing of dragon fruit peel by chemical method (soaking in 7.5\% acetic acid, $\mathrm{pH}$ of 4 for duration of four hours), biological method (fermentation using local microorganism solution from bamboo sprout with fermentation durations of 13 days, and inoculum dosage 6\%), and processing of dragon fruit peel with combination of physical-biological method decreased anthocyanin content from 198.87 to 144.98 , and 198.87 to 112.95 , and also 198.87 to $46.21 \mathrm{ppm}$. This research was related with Mulyawanti et al. (2018) indicating that anthocyanin of purple sweet potato slightly increased after steaming processing. Furthermore, fermentation blueberry using Lactobacillus reduced total anthocyanins content (29\%) compared with fresh blueberry (Nie et al., 2017). It was similar with the findings of Hornedo et al. (2017) indicating that Fermentation process decreased anthocyanin content from strawberry. Wiczkowski et al. (2015) reported that anthocyanin content from red cabbage reduced after fermentation.

The highest content of anthocyanin in dragon fruit peel which was processed by physical method due to degradation of $\beta$-(1,4)-glycoside bond in crude fiber fraction of dragon fruit peel cell by steaming, so that the anthocyanin came out easily from inside of the cell to solution ( $\mathrm{KCl}$ and natrium acetic) when dragon fruit peel maceration processed. Processing of dragon fruit peel by chemical method caused low level of anthocyanin content in comparing with control and physical method, this condition was correlated with crude fiber content in physical method that indicated more decrease than chemical method, it caused low levels of anthocyanin coming out of cells in chemical method than physical method. The processing of dragon fruit peel via biological method was possible by local microorganism from bamboo sprout, consist of bacteria (Lactobacillus, Streptococcus, Azotobacter, Azospirilium) and fungi (Fusarium and Trichoderma) (Fatoni, 2016). The loss of total anthocyanins content by fermentation was related to the unstable structure of blueberry anthocyanins during fermentation (Nie et al., 2017). This condition was a reason of decreased anthocyanin content of dragon fruit peel in biological method compared to anthocyanin content from dragon fruit without processing method or control, physical methods, and chemical methods in the current experiment. The lowest content of anthocyanin in dragon fruit peel was processed by combination of physical-biological method due to degradation of $\beta-(1,4)$ glycoside bonds in crude fiber fraction of dragon fruit peel cells by steaming, so that the anthocyanin came out easily from cells, and easier for microorganism to make anthocyanin structure unstable. Khazaei et al. (2014) reported that the processing by some methods like heat processing and fermentation would destroy anthocyanin structure and quantity, because of some factors like enzyme, $\mathrm{pH}$, and temperature would affect the anthocyanin stability and quantity.

The result of anthocyanins from dragon fruit peel processed by different methods with SEM are presented in figure 1. The image of each anthocyanins from dragon fruit peel after processing by different methods indicated changing on their surface image.

SEM observation showed that anthocyanin image from dragon fruit peel before being treated (See figure 1A and 1a), have many white spots, and after being treated by physical (steaming in boil water at $98^{\circ} \mathrm{C}$, at figure $1 \mathrm{~B}$ and 1b), the white spots increased, then being treated by chemical (soaking in acetic acid solution at $\mathrm{pH} 4$, at figure 1C and 1c), white spots decreased, and also being treated by biological (fermentation with local microorganism from bamboo sprout, at figure 1D and 1d), the white spots vanished, and the surface wrinkled, and combination physical-biological method (Figure 1E and 1e), the image showed white spot turned in to black spot. Therefore, anthocyanin image of dragon fruit peel for control was the same with physical, and different from chemical, biological, and combination of physical-biological methods. It means that the anthocyanins of dragon fruit peel treated by physical method was equal with anthocyanin from untreated dragon fruit peel (control), while the image of dragon fruit peel treated by physical method was not destroyed. The anthocyanin of dragon fruit peel processed by other methods (chemical, biological, and combination of physical-biological) showed a different image of anthocyanin in control and physical methods. It means that the processing (chemical, biological, and combination of physical-biological) affected the anthocyanin. 


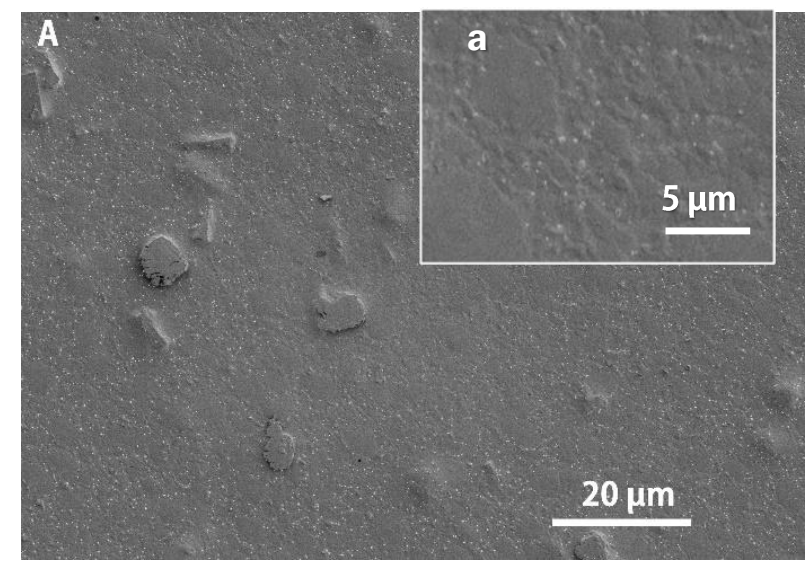

(A) before treated

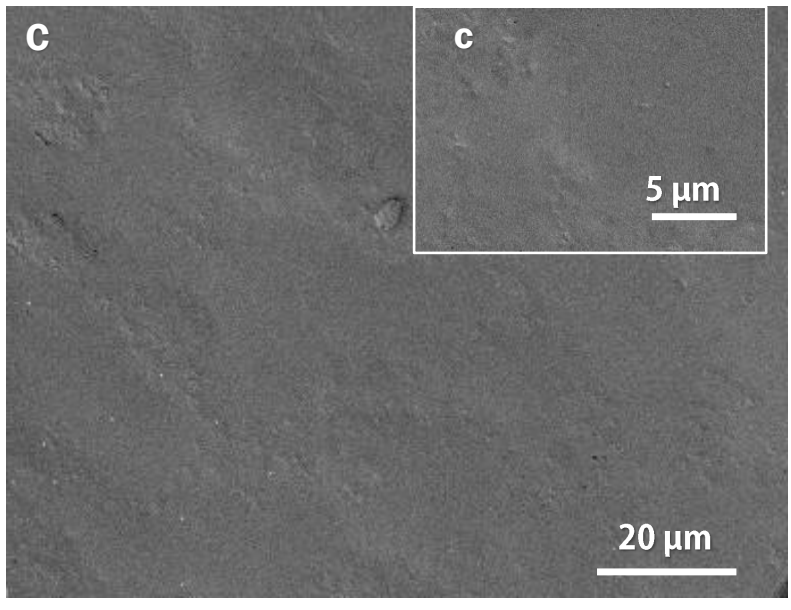

(C) after treated by chemical

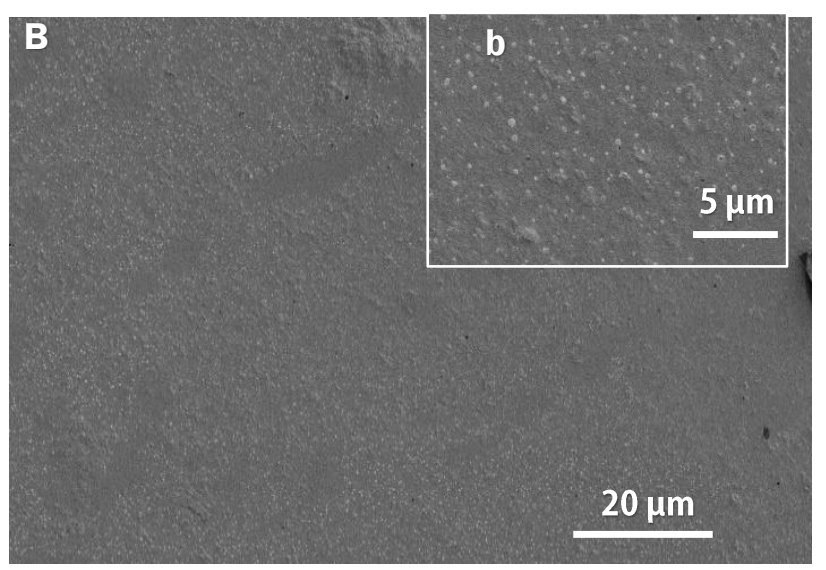

(B) after treated by physical

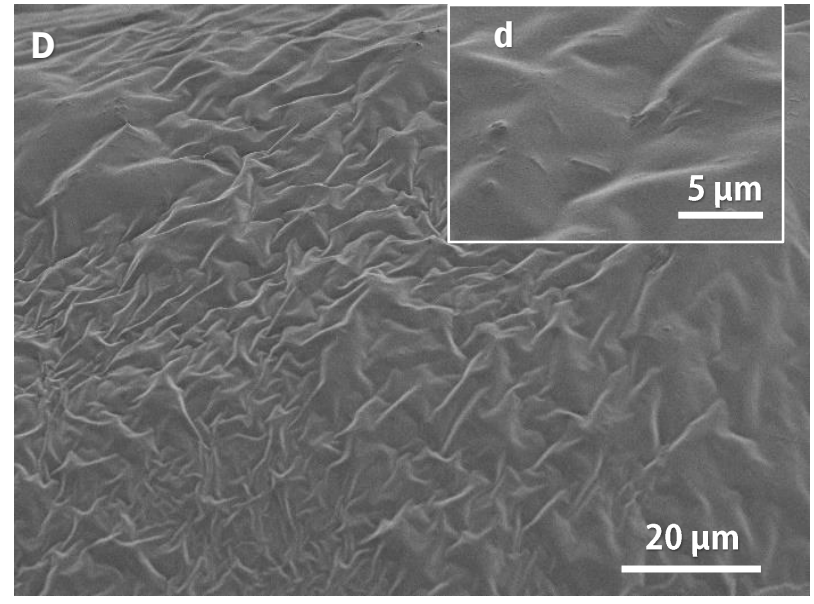

(D) after treated by biological

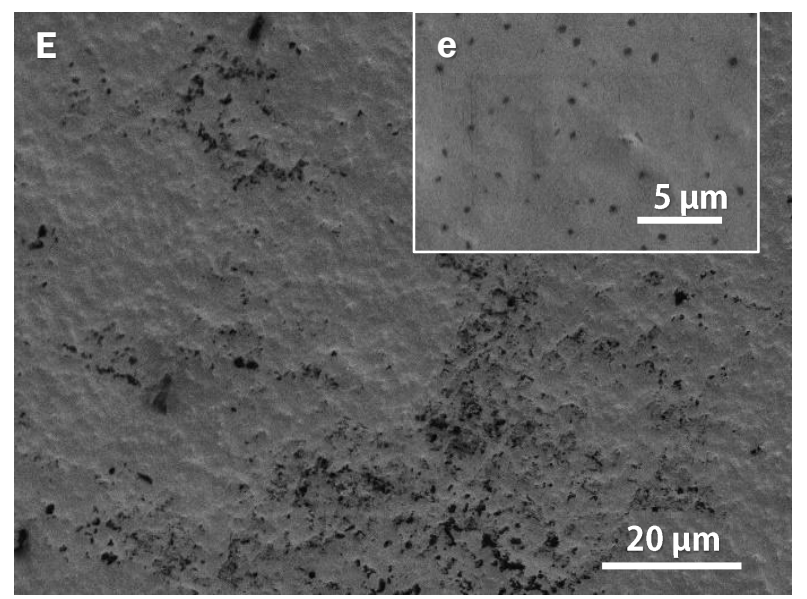

(E) after treated by combination physical-biological method

Figure 1. Scanning Electron Microscope (SEM) image of anthocyanin extract surface

\section{CONCLUSION}

Anthocyanin content in dragon fruit peel treated by physical method was higher than anthocyanin of dragon fruit peel treated by chemical, biological, and combination of physical-biological methods, and untreated dragon fruit peel (control). The image of anthocyanin of dragon fruit peel processed by physical method resembled the anthocyanin image of untreated dragon fruit peel, and the anthocyanin image of dragon fruit peel processed by 
chemical, biological and combination of physicalbiological methods was different compared to anthocyanin image of dragon fruit peel processed by physical method and untreated (control).

\section{DECLARATIONS}

\section{Acknowledgments}

This study was a part of main research for my $\mathrm{PhD}$ program at Universitas Andalas funded by the Ministry of Research, Technology and Higher Education of the Republic of Indonesia through PMDSU No: 059/SP2H1LT/DRPM/IV 2017. We are very grateful to the Rector of Universitas Andalas, and Nara Institute of Science and Technology (NAIST), Japan at Division of Materials Science as Host University for conducting a part of this research, and to the Minister of Research, Technology and Higher Education of the Republic of Indonesia for their support.

\section{Competing interests}

The authors declare that they have no competing interests.

\section{Author's contribution}

Mahlil wrote the paper, collected data, and performed statistical analysis, Mirzah, Warnita, Husmaini, and Mahata created the idea and designed the study. Kobayashi facilitate laboratory equipment, support on research and writing. Mahlil and Mahata drafted the manuscript and approved the final manuscript.

\section{Consent to publish}

All the authors gave their informed consent prior to their inclusion in the study.

\section{REFERENCES}

Adrizal, Heryandi Y, Amizar R and Mahata ME (2017). Evaluation of pineapple [Ananas comosus (L.) Merr] waste fermented using different local microorganism solutions as poultry feed. Pakistan Journal of Nutrition, 15 (2): 84-89. DOI: https://www.doi.org/10.3923/pjn.2017.84.89

Anggraeni CL (2010). Pengaruh pemberian ekstrak etanol ketan hitam (Oryza sativa Linn. var. glutinosa) terhadap kadar LDL dan HDL tikus yang diberi minyak goreng bekas pakai [the effect of black glutinous ethanol extract (Oryza sativa Linn. Var. Glutinosa) against LDL and HDL rats provided used cooking oil], Thesis, University Jember, Indonesia, pp. 1-54.

Charoensiri R, Kongkachuichai R, Suknicom S, and Sungpuag P (2009). Beta-carotene, lycopene, and alpha-tocopherol contents of selected Thai fruits. Food Chemistry, 113(1): 202-207. DOI: https://www.doi.org/10.1016/j.foodchem.2008.07.074

Echlin P (2009). Handbook of Sample Preparation for Scanning Electron Microscopy and X-Ray Microanalysis. DOI: https://www.doi.org/10.1007/978-0-387-85731-2
Fang J (2014). Bioavailability of Anthocyanins. Review Article. Drug Metabolism Reviews. 46(4): 508-520. DOI: https://www.doi.org/10.3109/03602532.2014.978080

Fatoni A (2016). Pengaruh mol rebung bambu (Dendrocalamus asper) dan waktu pengomposan terhadap kualitas pupuk dari sampah daun. Prosiding Seminar Nasional II, Kerjasama Prodi Pendidikan Biologi FKIP dengan Pusat Studi Lingkungan dan Kependudukan (PSLK) Universitas Muhammadiyah Malang Malang, University of Muhammadiyah Malang, Indonesia, pp. 876-881

Fayyaz S, Saddique S, Khalid H, Naureen S, Salman M, Islam M, Zahid F, Naheed S, Khan MT, Amjad S et al. (2016). Is quercetin accumulating in eggs using flavonoids-enriched poultry feed. Journal of Animal and Plant Sciences, 26(5): 1479-1485.

Giusti MM and Wrolstad RE (2001). Characterization and measurement of anthocyanins by UV-Visible spectroscopy. Current protocols in food analytical chemistry, Page: F1.2.1-F1.2.13. DOI: https://www.doi.org/10.1002/0471142913.faf0102s00

Handayani UF, Wizna, Suliansyah I, Rizal Y, and Mahata ME (2018). Effects of heating method on lycopene, dry matter and nutrient content of tomato (Lycopersicon esculentum) waste as laying hen feed. International Journal of Poultry Science, 17 (2): 63-70. DOI: https://www.doi.org/10.3923/ijps.2018.63.70

Heryandi Y, Adrizal, Ningsih N and Mahata ME (2018). Carcass characteristics and organ development of broilers fed fermented pineapple peel [Ananas comosus (L.) Merr] waste using a local microorganism solution derived from bamboo sprouts. International Journal of Poultry Science, 17 (5): 229-233. DOI: https://www.doi.org/10.3923/ijps.2018.229.233

Hornedo OR, Alvarez FMA, Cerezo AB, Garcia GI, Troncoso AM and Garcia PMC (2017). Influence of Fermentation Process on the Anthocyanin Composition of Wine and Vinegar Elaborated from Strawberry. Journal of Food Science, 82 (2): 364-372. DOI: https://www.doi.org/10.1111/1750-3841.13624

Iskander H, Yenice G, Dokumacioglu E, Kaynar O, Hayirli A and Kaya A (2017). Comparison of the effects of dietary supplementation of flavonoids on laying hen performance, egg quality and egg nutrient profile. British Poultry Science, 58(5): 550-556. DOI: https://www.doi.org/10.1080/00071668.2017.1349297

Khazaei K, Jafari SM, Ghorbani M and Hemmati KA (2014). Application of maltodextrin and gum Arabic in microencapsulation of saffron petal's anthocyanins and evaluating their storage stability and color. Carbohydrate Polymers, 105: 57-62. DOI: https://www.doi.org/10.1016/j.carbpol.2014.01.042

Khoo HE, Azlan A, Tang ST and Lim SM (2017). Anthocyanidins and anthocyanins: colored pigments as food, pharmaceutical ingredients, and the potential health benefits. Food and Nutrition Research, 61(1): 1361779. DOI: https://www.doi.org/ 10.1080/16546628.2017.1361779

Lapornik B, Prosek M and Wondra AG (2005). Comparison of Extracts Prepared from Plant By-products Using Different Solvents and Extraction Time. Journal of Food and Engineering, 71: 214-222. DOI: https://www.doi.org/10.1016/j.jfoodeng.2004.10.036

Lewis GF and Rader DJ (2005). New insights into the regulation of HDL metabolism and reverse cholesterol transport. American Heart Association, Circulation Research, 96: 1221-1232. DOI: https://www.doi.org/10.1161/01.RES.0000170946.56981.5c

Mahata ME, Mahlil Y, Fajri Y, Aditiya R, Hendro, Zahara A and Rizal Y (2015). The effect of dragon Fruit (Hylocereus polyrhizus) peel on broiler thigh meat quality and organ development, Proceedings book of abstract, XXII European Symposium on the Quality of Poultry Meat and the XVI European Symposium on the Quality of Eggs and Egg Product, Nantes, France. 82.

Mahata ME, Manik J, Taufik M, Rizal Y and Ardi (2016a). Effect of different combinations of unboiled and boiled tomato waste in diet on performance, internal organ development and serum lipid profile 
of broiler chicken. International Journal of Poultry Science, 15 (7): 283-286. DOI: https://www.doi.org/10.3923/ijps.2016.283.286

Mahata ME, Rizal Y and Wu G (2012). Improving the nutrient quality of juice waste mixture by steam pressure for poultry diet. Pakistan $\begin{array}{lllll}\text { Journal of Nutrition. } 11 & \text { (2): } 172-175 . \quad \text { DOI: }\end{array}$ https://www.doi.org/10.3923/pjn.2012.172.175

Mahata ME, Rizal Y, Ardi, Hermansyah D, and Nurhuda GA (2016b). Effect of boiled tomato waste utilization in diet on serum lipid profile and egg quality of laying-hens. International Journal of Poultry Science, $15 \quad$ (12): 493-496. DOI: https://www.doi.org/10.3923/ijps.2016.493.496

Mahlil Y, Husmaini, Warnita, Mirzah, and Mahata ME (2018a). Using physical and chemical methods to improve the nutrient quality of dragon fruit (Hylocereus polyrhizus) peel for use as feed for laying hens. International Journal of Poultry Science, 17 (2): 51-56. DOI: https://www.doi.org/10.3923/ijps.2018.51.56

Mahlil Y, Husmaini, Warnita, Mirzah, and Mahata ME (2018b). Improving of Dragon Fruit Peel Wastes Nutrient Quality by Fermentation with Local Microorganism from Bamboo Sprout for Laying Hens Feed. Abstract summary, Proceeding of conference, 23-24 August,2018. International conference on basic sciences and its applications (ICBSA). Hotel Grand Inna Muaro. Padang.

Mulyawanti I, Budijanto S and Yasni S (2018). Stability of Anthocyanin During Processing, Storage and Simulated Digestion of Purple
Sweet Potato Pasta. Indonesian Journal of Agricultural Science, 19(1): 1-8. DOI: https://www.doi.org/10.21082/ijas.v.19. n1.2018. pp. $1-8$.

Nie Q, Feng L, Hu J, Wang S, Chen H, Huang X, Nie S, Xiong T and Xie $M$ (2017). Effect of fermentation and sterilization on anthocyanins in blueberry. Journal of the Science of Food and Agriculture, 97 (5): 1459-1466. DOI: https://www.doi.org/10.1002/jsfa.7885

Rizal Y, Nuraini, Mirnawati and Mahata ME (2013). Comparisons of nutrient contents and nutritional values of palm kernel cake fermented by using different fungi. Pakistan Journal of Nutrition, 12 (10): 943-948. DOI: https://www.doi.org/10.3923/pjn.2013.943.948

Steel RGD and Torrie JH (1991). Prinsip dan Prosedur Statistika [Principal and Statistical Procedure]. Translated by Bambang Sumantri, PT. Gramedia Pustaka Utama, Jakarta.

Wiczkowski W, Nowak DS and Topolska J (2015). Changes in the content and composition of anthocyanins in red cabbage and its antioxidant capacity during fermentation, storage and stewing. Food Chemistry, 167 (2015): 115-123. DOI: https://www.doi.org/10.1016/j.foodchem.2014.06.087

Wu L, Hsu HW, Chen YC, Chiu CC, Lin YI and Ho JA (2006). Antioxidant and antiproliferative activities of red pitaya. Food Chemistry, 95(2): 319-327. DOI: https://www.doi.org/10.1016/j.foodchem.2005.01.002 